\title{
Self Regulation, Self Esteem, dan Self Concept Berpengaruh terhadap Prestasi Belajar Matematika Peserta Didik
}

\author{
Ummi Rofika Hasan ${ }^{1 \bowtie}$, Fitriani Nur ${ }^{2}$, Ulfiani Rahman ${ }^{3}$, Suharti $^{4}$, dan Eka Damayanti ${ }^{5}$ \\ 1,2,3,4,5 Prodi Pendidikan Matematika, UIN Alauddin Makassar
}

\section{Info Artikel Abstract}

Sejarah Artikel:

Diterima 31 Des 2020

Direvisi 24 Mar 2021

Disetujui 17 Apr 2021

Keywords: Self regulation, self esteem, self concept, learning achievement.

\section{Paper type:}

Research paper
The purpose of this study was to determine the effect of self regulation, self esteem and self concept. These independent variables are factors within students who have an important role in the learning process. So that the factors in these students become the core in this research study. This type of research is ex post facto involving grade VIII students of SMPN 5 Makassar with a total sample of 168 students. Data collection techniques used questionnaire instruments of self regulation, self esteem and self concept and documentation data in the form of student achievement scores that had passed the validation process. Furthermore, the collected data were analyzed by using multiple linear regression after passing the prerequisite test process. The conclusion of this study shows that self-regulation, self-esteem and self-concept together have an effect on the learning achievement of class VIII students of SMAN 5 Makassar with a large influence of $90.2 \%$ and the remaining $9.8 \%$ is influenced by other factors. This shows that the factors from within these students have an important role in the success of students in the learning process.

\begin{abstract}
Abstrak
Tujuan penelitian ini yaitu untuk mengetahui pengaruh self regulation, self esteem dan self concept. Variabel-variabel independen tersebut merupakan faktor dalam diri siswa yang memiliki peranan penting dalam proses pembelajaran. Sehingga faktor dalam diri siswa tersebut menjadi inti dalam kajian penelitian ini. Jenis penelitian ini adalah expost facto yang melibatkan siswa kelas VIII SMPN 5 Makassar dengan jumlah sampel 168 siswa. Teknik pengumpulan data menggunakan instrument angket self regulation, self esteem dan self concept dan data dokumentasi berupa skor prestasi belajar siswa yang telah melewati proses validasi. Selanjutnya data yang terkumpul dianalisis dengan uji regresi linear berganda setelah melewati proses uji prasyarat. Simpulan dari penelitian ini menunjukkan self regulation, self esteem dan self concept secara bersama-sama berpengaruh terhadap prestasi belajar peserta didik kelas VIII SMAN 5 Makassar dengan besar pengaruh $90,2 \%$ dan sisanya sebesar 9,8\% dipengaruhi oleh faktor lain. Hal ini menunjukkan bahwa faktor dari dalam diri siswa tersebut memiliki peranan penting dalam keberhasilan peserta didik dalam proses belajar.
\end{abstract}

(C) 2021 Universitas Muria Kudus

\footnotetext{
๑lamat korespondensi:

Program Studi Pendidikan Matematika

Fakultas Keguruan dan Ilmu Pendidikan Universitas Muria Kudus

Kampus UMK Gondangmanis, Bae Kudus Gd. L. 1t I PO. BOX 53 Kudus

Tlp (0291) 438229 ex.147 Fax. (0291) 437198

E-mail: fitrianinur@uin-alauddin.ac.id
}

p-ISSN 2615-4196

e-ISSN 2615-4072 


\section{PENDAHULUAN}

Di dalam Islam, pendidikan memiliki makna yang sangat penting sebab ruh ialah awal dari diturunkannya wahyu Allah.swt. Membaca menjadi perintah pertama di dalam islam. Dalam hal ini, membaca diartikan secara lebih luas yang mencakup di dalamnya yaitu: mengkaji, meneliti, memahami, mengobservasi, melakukan proses pembelajaran dan proses pendidikan. Contoh bidang yang memegang peran penting untuk meningkatkan mutu pendidikan adalah matematika. Hal ini mampu diketahui dengan ditetapkannya mata pelajaran matematika sebagai mata pelajaran pokok ataupun wajib pada pelaksanaan UAN (Ujian Akhir Nasional) dan memperbanyak jumlah jam pelajaran matematika di sekolah. Pembelajaran matematika dapat diartikan sebagai suatu proses dimana siswa akan secara aktif mengonstruksi pengetahuan matematika (Erman, dkk., 2003).

Peningkatan kualitas pendidikan dapat diketahui dengan memerhatikan prestasi atau kinerja belajar yang dicapai siswa. Winkel mengemukakan bahwa prestasi belajar diartikan sebagai bukti bukti dari keberhasilan belajar atau kemampuan yang dimiliki oleh pelajar dalam menjalankan kegiatan belajarnya sesuai dengan bobot yang kemudian dapat dinyatakan ke dalam rapor, angka kelulusan, indeks prestasi studi, serta predikat keberhasilan.

Prestasi dalam belajar bisa dimaknai sebagai hasil atau efek dari proses kegiatan belajar. Jadi prestasi ialah besarnya nilai tes yang didapat siswa selama proses interaksi pembelajaran berlangsung setelah diberikan perlakuan. Proses belajar membuat suatu perubahan pada diri siswa sebagai akibat dari proses transfer ilmu baik pengetahuan, pemahaman, sikap, maupun keterampilan (Nana Sudjana, 2009). Sedangkan Prestasi Belajar matematika dapat diartikan sebagai perubahan budi pekerti yang didapat dari berbagai pengalaman yang dimiliki oleh siswa pada beberapa kegiatan tentang pemecahan masalah, dimana kegiatan tersebut berupa pengumpulan data, pencarian hubungan antara dua hal, kegiatan menghitung, penyusunan hipotesis, kegiatan penyamarataan dan sebagainya. Sehingga didapat beberapa konsep dari berbagai hukum matematika dengan baik. Hasil dari proses belajar menurut Bloom dalam Sudjana (2009) adalah perubahan budi pekerti yang mencakup tiga ranah, yaitu: afektif, kognitif, dan psikomotorik. Oleh karena itu, bisa disimpulkan bahwa prestasi belajar ialah banyaknya kemampuan yang dimiliki oleh siswa setelah melewati berbagai pengalaman belajar.

Berdasarkan hasil observasi pada tanggal 15-17 April 2019 menyatakan bahwa prestasi belajar yang dimiliki oleh siswa belum mencerminkan hasil yang maksimal. Hal ini dapat dilihat dari jumlah siswa kelas VIII SMPN 5 Makassar secara keselurahan yaitu 373 siswa. Terdapat $80 \%$ siswa yang nilainya belum mencapai standar KKM (Kriteria Ketuntasan Minimal) baik saat ulangan harian, UTS (Ujian Tengah Semester), UAS (Ujiah Akhir Sekolah) maupun pada nilai rapor yang merupakan hasil akhir pembelajaran siswa. Setelah dilakukannya wawancara kepada 2 guru matematika kelas VIII, diperoleh adanya beberapa faktor yang memengaruhi rendahnya prestasi belajar matematika, diantaranya dikarenakan minat siswa dalam mengikuti pelajaran matematika yang tidak tampak. Para siswa kurang mampu mengajukan idenya, kemampuan siswa untuk memperbaiki diri juga terbilang rendah, kemudian kurangnya kemampuan siswa ketika mengerjakan tugas matematika dimana banyak siswa yang melihat atau meniru pekerjaan siswa lain. Permasalahan di atas menunjukkan bahwa rendahnya regulasi diri atau self regulation pada siswa yang artinya siswa belum mampu menerapkan self regulation pada diri siswa. Selain itu, siswa juga kurang memperoleh kepercayaan dan penghargaan dari orang lain. Hal ini disesuaikan dari rendahnya perasaan tenang, yakin dan mampu siswa dalam melaksakan suatu tugas. Permasalahan di atas menunjukan bahwa harga diri (self esteem) yang dimiliki siswa cenderung rendah. Sehingga self esteem sangat mempengaruhi prestasi belajar matematika siswa. Dimana semakin tinggi self esteem maka semakin tinggi pula prestasi belajar matematika siswa.

Permasalahan lain juga terjadi pada siswa kelas VIII SMPN 5 Makassar, yaitu siswa menganggap matematika sebagai ilmu yang sulit dipahami. Permasalahan tersebut timbul karena penguasaan konsep dasar matematika pada siswa masih lemah, hal ini terlihat ketika siswa selalu merasa cemas dan tegang saat akan mengikuti pelajaran matematika, bahkan saat akan menghadapi kuis, UTS ataupun UAS. Keyakinan siswa yang menganggap kemampuan dirinya masih kurang terlihat dari kekurangyakinan ketika mengerjakan soal latihan, tugas dan ujian, serta kurang mampu memberikan argument yang tepat terhadap hasil dari tugas yang dikerjakannya (Mahayukti et al., 2020). Permasalahan diatas menunjukan bahwa rendahnya konsep diri atau 
self concept siswa pada mata pelajaran Matematika. Sehingga terdapat pengaruh anatra self concept dengan prestasi belajar.

Beberapa permasalahan yang sudah dipaparkan sebelumnya bisa terjadi sebab ada pengaruh faktor dari dalam diri siswa (Tamaruddin \& Fathurohman, 2020). Melihat fakta yang sudah terjadi di lapangan bahwa perilaku yang muncul yaitu: tidak dapat mengukur diri dengan baik, harga diri rendah, tidak mempunyai pengaturan diri yang bagus, merasa tidak memiliki potensi, motivasi belajar rendah, rasa percaya diri yang kurang, mudah putus asa, dan senang mengkritik diri sendiri sehingga membuat siswa akan menanggapi segala sesuatu dengan pandangan yang buruk. Oleh karenanya, perlu adanya tindak lanjut dalam hal meningkatkan prestasi belajar siswa. Tugas pendidik saat mengajar di kelas bukan cuma menyajikan bahan ajar saja, tetapi juga dapat menciptakan kondisi belajar yang positif yang dapat berupa pemberian penjelasan, petunjuk, dorongan, dan rangsangan serta meningkatkan sikap persaingan positif dari setiap siswa (Nurafni \& Pujiastuti, 2019). Dengan menciptakan iklim persaingan yang baik di kelas maka setiap siswa bisa mengembangkan dirinya menjadi lebih baik (Friskilia \& Winata, 2018).

Kemampuan self regulation, self esteem dan self concept siswa termasuk faktor psikologis yang bisa meningkatkan prestasi belajar pelajar. Woolfolk mengatakan bahwa kemampuan melakukan regulasi diri adalah salah satu faktor personal yang bisa memengaruhi prestasi seseorang (Friskilia \& Winata, 2018). Yakni berupa kemampuan untuk menghasilkan perasaan, pikiran, tindakan serta merencanakan dan mengadaptasikannya secara berlanjut demi mencapai tujuan (Zimmerman, 2000).

Regulasi diri dalam ilmu psikologi dikenal dengan istilah Self Regulation. Dalam teori kognisi sosial, regulasi diri secara luas dipandang sebagai suatu proses sistematis yang terdiri dari pemikiran dan perilaku manusia yang melibatkan pengaturan dan mengarahkan diri sendiri menuju pencapaian sebuah tujuan (Bryant, 2007). Zimmerman \& Cleary (2004: 12) berpendapat bahwa regulasi diri secara umum melibatkan individu yang proaktif untuk mengarahkan perilaku mereka atau strategi dalam mencapai tujuan yang ditetapkannya. Mereka juga mengandalkan afektif, kognitif, motivasi, juga umpan balik perilaku demi mengubah atau menyesuaikan strategi dan sikap untuk mencapai tujuan mereka (Zamnah, 2019).
Menurut Zimmerman dan Williamson (2015) terdapat 3 aspek regulasi diri, yaitu motivasi diri, metakognisi, serta perilaku. Metakognisi merupakan kemampuan manusia untuk merencanakan, memerintahkan diri, memantau, mengatur, mengadakan evaluasi dan mengorganisasikan aktivitasnya (Zulfikar \& Tamrin, 2019). Motivasi merupakan keseluruhan daya penggerak dari dalam diri dengan menimbulkan rasa ingin belajar, menjamin berlngsungnya kegiatan belajar, serta memberi arah pada kegiatan belajar. Salah satu aspek regulasi diri adalah perilaku. Perilaku memberikan feedback yang berorientasi pada diri individu dalam bentuk mengevaluasi tingkah laku yang telah dilakukan individu, dan sejauh mana individu meregulasi dirinya ke arah tujuan yang telah ditetapkan

Faktor psikologis yang juga mempengaruhi prestasi belajar adalah self esteem. Self esteem (harga diri) memberikan pengaruh yang cukup maksimal terhadap harapan, tingkah laku, juga penilaian individu yang berkaitan dengan dirinya maupun orang lain. Self esteem yang merupakan komponen afektif, kognitif, dan evaluative bukan hanya berupa masalah pribadi maupun psikologis tetapi juga berupa interaksi sosial. Sehingga dapat dikatakan bahwa self esteem ialah sikap, baik positif ataupun negative terhadap seseorang (Mruk, Christopher J., 2006).

Rosenberg Self Esteem Scale merupakan salah satu alat ukur yang dikembangkan sejak lama dan merupakan alat ukur self esteem yang paling sering dipakai sampai sekarang. Alat ukur tersebut menekankan pada feelings atau perasaan Rosenberg dalam Emler (2001: 11-12). Sepuluh item yang dijabarkan dalam alat ukur tersebut terdiri dari: 1) perasaan sebagai seseorang yang berguna atau minimal sama seperti orang lain, 2) perasaan menjadi seseorang yang memiliki kualitas yang baik, 3) condong merasa sebagai seseorang yang gagal, 4) kemampuan untuk melakukan banyak hal sebaik mungkin seperti kebanyakan yang dilakukan orang, 5) merasa tidak memiliki banyak hal yang bisa dibanggakan 6) memiliki sikap positif kepada diri sendiri, 7) secara umum, merasa puas dengan diri sendiri, 8) berharap untuk lebih menghargai diri sendiri 9) sering kali merasa tidak berguna, 10) sering kali berpikir bahwa saya bukanlah orang yang baik.

Hal ini juga terjadi pada self concept dalam mempengaruhi prestasi belajar. Self concept didefinisikan sebagai perspektif seorang individu terhadap dirinya sendiri dengan melihat kekurangan juga kelebihannya, termasuk dalam 
merencanakan visi dan misi hidup (Sumartini, 2014). Salah satu bagian yang penting dalam perkembangan kepribadian seseorang adalah self concept, sebagaimana yang dikatakan oleh Rogers bahwa diri (self) merupakan konsep yang paling mayoritas dari kepribadian. Diri berisikan berbagai ide, persepsi-persepsi, serta nilai-nilai yang mencakup kesadaran tentang diri sendiri (Desmita, 2009).

Calhoun dan Acocella dalam Gufron \& Risnawati (2016) membagi aspek self concept menjadi tiga yakni pengetahuan, harapan, serta penilaian. Aspek pengetahuan dari self concept berupa segala hal yang berkaitan dengan "siapakah saya" yang selanjutnya akan memberikan gambaran mengenai dirinya sendiri dan kemudian akan membangun kesan terhadap diri. Aspek harapan dari self concept berupa harapan dari dalam diri sendiri yang telah dicitacitakan untuk masa depan. Pada saat kita memiliki banyak pandangan tentang diri kita yang sebenarnya, maka saat itu juga kita mempunyai banyak pandangan lain tetang kemungkinan akan menjadi seperti apa kita di masa depan. Aspek penilaian self concept berupa penilaian terhadap diri sendiri. Penilaian self concept ialah pandangan mengenai kewajaran kita sebagai individu seperti standarisasi yang telah kita tetapkan bagi diri sendiri serta pengharapan bagi diri sendiri. Penulis dalam artikel ini hendak membuktikan bahwa prestasi belajar matematika dipengaruhi oleh self regulation, self esteems dan self concept peserta didik. Hal itu didasari dari asumsi bahwa ketiga variable tersebut secara teori atau pendapat para ahli berdampak pada prestasi belajar matematika.

\section{METODE PENELITIAN}

Penelitian ini mengadaptasi jenis penelitian expostfacto yakni penelitian yang bertujuan untuk menemukan kemugkinan penyebab terjadinya perubahan perilaku, fenomena atau gejala yang disebabkan oleh peristiwa, perilaku atau beberapa hal lain yang menjadi penyebab terjadinya suatu perubahan pada variabel bebas dan secara komprehensif telah terjadi serta menjelaskan bagaimana beberapa variabel dalam suatu penelitian saling memberi pengaruh. Desain penelitian ini yakni paradigma ganda dengan 2 variabel bebas (independen) dan 1 variabel terikat (dependen).

Populasi pada penelitian ini yaitu keseluruhan siswa di kelas VIII dari SMP Negeri 5 Makassar dengan 9 kelas yang jumlah siswanya sekitar 373 orang dengan penyebaran secara heterogen (ada pengelompokan antara siswa dengan kecerdasan tinggi dan siswa dengan kecerdasan rendah). Penulis berpedoman pada table Isaac dan Michael dalam menentukan besarnya sampel yang diteliti. Tabel tersebut dapat memberikan kemudahan dalam menentukan banyaknya sampel sesuai dengan tingkatan kesalahan 1\%, 5\%, dan 10\%. Sehingga peneliti bisa secara langsung menentukan besaran sampel dari populasi sekaligus tingkat kesalahan yang diinginkannya(Indrawan \& Yaniawati, 2014). Apabila populasi berjumlah 373 maka banyaknya sampel yang dipilih adalah 50\% dari populasi sehingga jumlah sampelnya 168 siswa dengan taraf signifikansi 5\%.

Pengumpulan data prestasi belajar peserta didik menggunakan, data dokumentasi berupa skor prestasi belajar. Selain itu untuk variable bebas, pengumpulan data dilakukan menggunakan angket berupa skala psikologi self regulation, self esteem dan self concept yang disusun oleh peneliti berdasarkan aspek/indikator yang dikemukakan para ahli. Lebih lengkapnya lihat pada Tabel berikut.

Tabel 1. Indikator variabel self regulation, self esteem, dan self concept

\begin{tabular}{clc}
\hline Variabel & \multicolumn{1}{c}{ Aspek/Indikator } & $\begin{array}{c}\text { Jumlah } \\
\text { Item }\end{array}$ \\
\hline self regulation & $\begin{array}{l}\text { Metakognisi, motivasi dan } \\
\text { perilaku }\end{array}$ & 30 \\
self esteem & $\begin{array}{l}\text { Keberartian diri, kekuatan } \\
\text { individu, kompetensi } \\
\text { individu, dan ketatan } \\
\text { individu, }\end{array}$ \\
self concept & $\begin{array}{l}\text { Pengetahuan, harapan dan } \\
\text { penilaian }\end{array}$ \\
\hline
\end{tabular}

Data yang terkumpul dianalisis menggunakan analisis regresi linear berganda untuk memberikan pembuktian dari pengaruh self regulation $\left(\mathrm{X}_{1}\right)$, self esteem $\left(\mathrm{X}_{2}\right)$ dan self concept $\left(\mathrm{X}_{3}\right)$ secara bersaman terhadap prestasi belajar matematika peserta didik (y).

\section{HASIL DAN PEMBAHASAN}

Sebelum mengolah data menggunakan sebuah analisis regresi, terlebih dahulu kita melakukan sebuah uji prasyarat yang meliputi uji linearitas, uji normalitas, uji heteroskedastisitas dan uji multikolinearitas. Pengujian normalitas dilakukan terhadap data self regulation, self esteem dan self concept dan Prestasi Belajar matematika menggunakan sebuah teknik Kolmogorov-smirnov dan bantuan SPSS generasi ke 20 yang dilakukan pada masing-masing 
Ummi Rofika Hasan, Fitriani Nur, Ulfiani Rahman, Suharti, dan Eka Damayanti

Anargya: Jurnal Pendidikan Matematika, Vol. 4 No.1, April 2021

https://dx.doi.org/10.24176/anargya.v4i1.5715

kelompok. Kesimpulan dari hasil uji normalitas dapat kita lihat pada Tabel 2 berikut ini.

Tabel 2. Hasil uji normalitas

\begin{tabular}{cccc}
\hline Variable & $\begin{array}{c}\text { Test } \\
\text { Statistic }\end{array}$ & Sig & Keterangan \\
\hline $\begin{array}{c}\text { Self regulation } \\
\left(\mathrm{X}_{1}\right)\end{array}$ & 0,83 & 0,381 & Normal \\
$\begin{array}{c}\text { Self esteem } \\
\left(\mathrm{X}_{2}\right)\end{array}$ & 0,12 & 0,137 & Normal \\
$\begin{array}{c}\text { Self concept } \\
\left(\mathrm{X}_{3}\right)\end{array}$ & 0,64 & 0,267 & Normal \\
$\begin{array}{c}\text { Prestasi } \\
\text { Belajar } \\
\text { matematika } \\
(\mathrm{Y})\end{array}$ & 0,59 & 0,200 & Normal \\
\hline
\end{tabular}

Berdasarkan dari hasil output menggambarkan ke empat variable tersidstribusi normal yang dibuktikan dengan nilai sig Self regulation $(0,0381>0,05)$, self esteem $(0,137>$ $0,05)$, Self concept $(0,0267>0,05)$, dan data prestasi belajar matematika $(0,200>0,05)$.

Pengujian linearitas untuk persamaan regresi ditentukan berdasarkan tabel ANOVA dengan bantuan komputerisasi. Hasil uji linearitas menunjukkan ketiga variable bebas memiliki data yang linear terhadap variable prestasi belajar. Hal itu dibuktikan dengan nilai sig $>$ dari $\alpha 0,05$

Tabel 3. Hasil uji linearitas

\begin{tabular}{cccc}
\hline Korelasi & F & Sig. & Keterangan \\
\hline $\mathrm{X}_{1} \mathrm{Y}$ & 0,780 & 0,775 & Linear \\
$\mathrm{X}_{2} \mathrm{Y}$ & 1,557 & 0,087 & Linear \\
$\mathrm{X}_{3} \mathrm{Y}$ & 2,440 & 0,763 & Linear \\
\hline
\end{tabular}

Self regulation terhadap prestasi belajar matematika $(0,775>\alpha)$, self esteem terhadap prestasi belajar matematika $(0,087>\alpha$ self concept terhadap prestasi belajar matematika $(0,763>\alpha)$

Hasil uji multikolinieritas menunjukkan tidak terjadi multikolinearitas pada ketiga veriabel bebas sehingga dapat dikatakan model di atas terhindar dari multikolinearitas.

Tabel 4. Hasil uji multikolinearitas

\begin{tabular}{ccc}
\hline Variabel & Tolerance & Vif \\
\hline Self regulation & 0,664 & 1,505 \\
Self esteem & 0,774 & 1,292 \\
Self concept & 0,625 & 1,600 \\
\hline
\end{tabular}

Hasil uji heteroskedastisitas yang menggunakan uji Rank Spearman menunjukkan tidak ada masalah ataupun gejala heteroskedastisitas. Oleh katena itu model dari regresi yang digunakan pada penelitian ini layak digunakan.

Tabel 5. Hasil uji heteroskedastisitas

Variabel Sig. (2-Tailed)

\begin{tabular}{cc}
\hline Self regulasion & 0,134 \\
self esteem & 0,619 \\
Self concept & 0,023 \\
\hline
\end{tabular}

Setelah melalui uji prasyarat, terlebih dahulu dilakukan analisis regresi linier berganda menggunakan bantuan komputerisasi untuk membuktikan Self Regulation, Self Esteem dan Self Concept berpengaruh pada prestasi belajar matematika peserta didik kelas VIII SMAN 5 Makassar.

Tabel 6. Hasil analisis regresi berganda

\begin{tabular}{cccc}
\hline Variabel & $\mathbf{B}$ & $\mathbf{t}$ & Sig \\
\hline Self regulation & 0,961 & 21,492 & 0,000 \\
self esteem & 0,069 & 1,102 & 0,274 \\
Self concept & 0,005 & 0,082 & 9,935 \\
\hline
\end{tabular}

Berdasarkan pada tabel coefficients (a) menyatakan bahwa model persamaan regresi berganda dalam memperkirakan prestasi belajar matematika yang dipengaruhi oleh Self Regulation, Self Esteem dan Self Concept adalah:

$$
\mathrm{Y}=0,815+0,961 \mathrm{X}_{1}+0,069 \mathrm{X}_{2}+0,005 \mathrm{X}_{3}
$$

$\mathrm{Y}$ merupakan prestasi belajar matematika, $\mathrm{X}_{1}$ merupakan self regulation, $\mathrm{X}_{2}$ self esteem dan $\mathrm{X}_{3}$ adalah self concept. Dari hasil persamaan tersebut, dapat kita analisis mengenai beberapa hal antara lain: Kemampuan Prestasi Belajar matematika, jika tanpa Self Regulation, Self Esteem dan Self Concept $\left(\mathrm{X}_{1}=0, \mathrm{X}_{2}=0\right.$ dan $\left.\mathrm{X}_{3}=0\right)$, maka Prestasi Belajar dari matematika hanya 0,815 . Koefisien dari regresi berganda sebesar 0,961, 0,069 dan 0,005 mengindikasikan besarnya penambahan dari tingkat Prestasi Belajar matematika untuk Self Regulation, Self Esteem dan Self Concept.

Langkah selanjutnya adalah pengujian simultan. Pengujian simultan adalah pengujian secara Bersama koefisien variabel self regulation, self esteem dan self concept $\left(\mathrm{b}_{1}, \mathrm{~b}_{2}\right.$, dan $\left.\mathrm{b}_{3}\right)$ terhadap prestasi belajar matematika.

Tabel 7. Hasil anova (a) dengan SPSS 20

\begin{tabular}{cccccc} 
Reg. & $\mathbf{R}$ & $\mathbf{R}^{2}$ & $\mathbf{F}$ & Sig & Kesimpulan \\
& & & & & \\
\hline $\mathrm{X}_{1} \mathrm{X}_{2}$ & 0,9 & 0,9 & 241, & 0,0 & $\begin{array}{c}\text { Berpengaruh positif } \\
\text { dan signifikansi }\end{array}$ \\
$\mathrm{X}_{3} \mathrm{Y}$ & 50 & 02 & 867 & 00 & \\
\hline
\end{tabular}

Berdasarkan tabel 7, didapatkan nilai $\mathrm{R}_{\mathrm{XY}}$ yaitu 0,950. Dari hal tersebut terjadi pengaruh yang cukup erat antara self regulation, self esteem dan self concept terhadap Prestasi Belajar matematika siswa. 
Berdasarkan dari hasil analisis data yang telah dilakukan maka diperoleh kesimpulan yaitu terdapat yang pengaruh signifikan (sig. $<0,05)$ antara self regulation, self esteem dan self concept terhadap Prestasi Belajar matematika kelas VIII SMPN 5 Makassar.

Besar pengaruhnya dapat dilihat dengan nilai $\mathrm{R}^{2}$ ( $\mathrm{R}$ square) yaitu 0,902 atau $(90,2 \%)$. hal ini menunjukkan terdapat hubungan yang erat antara self regulation, self esteem dan self concept terhadap prestasi belajar matematika peserta didik kelas VIII SMP Negeri 5 Makassar yakni sebesar $90,2 \%$ dan sisanya $9,8 \%$ terpengaruh oleh variabel lain yang tidak masuk dalam model penelitian ini.

Prestasi Belajar yang telah dicapai oleh siswa pada penelitian ini dipengaruhi faktor psikologis yang ada dalam diri manusia. Faktor psikologis merupakan keadaan orang yang mempengaruhi proses belajar dan keberhasilan belajar dengan mencakup hal yang berhubungan dengan kondisi mental seseorang. Kondisi mental dengan kondisi yang baik dan stabil dapat menunjang keberhasilan belajar (Syah, 2008).

Pada proses belajar, siswa menggunakan dari kemampuan mentalnya agar dapat mempelajari matematika. Sehingga kemampuan afektif, kognitif, dan psikomotorik yang telah dibelajarkan menggunakan bahan ajar menjadi rinci dan menguat. Dengan adanya informasi mengenai sasaran belajar, adanya penguatan, adanya evaluasi dan keberhasilan proses belajar, menyebabkan siswa akan semakin sadar mengenai kemampuan dirinya dan mendapatkan Prestasi Belajar matematika yang baik.

Faktor lain diluar variable penelitian ini diduga mempengaruhi prestasi belajar dapat berasal dari pengetahuan siswa yang rendah, karena semakin banyak ataupun beragam pengetahuan yang dimiliki siswa maka semakin membantu siswa dalam melakukan sebuah regulasi. Faktor lain seperti tujuan yang ingin dicapai siswa juga mempengaruhi rendahnya self regulation, karena dengan semakin banyak dan kompleks tujuan yang akan diraih, semakin besar juga kemungkinan siswa melakukan regulasi diri.

Oleh karena itu, jalan yang dapat ditempuh dalam meningkatkan dan mengoptimalkan Prestasi Belajar siswa yaitu dengan meningkatkan self regulation (regulasi diri) siswa dalam belajar matematika. Regulasi diri memiliki peran yang penting. Apabila seorang siswa tidak mempunyai self regulation yang besar terhadap objek yang dipelajarinya, maka siswa akan sulit untuk diharapkan tekun dan memperoleh hasil baik dari belajarnya. Sebaliknya, apabila belajar dengan self regulation yang besar dari objek yang dipelajarinya, maka hasil yang diperoleh akan lebih baik. Karena self regulation akan menjadi terwujud apabila siswa aktif dalam mengontrol sendiri segala sesuatu yang dikerjakan, mengevaluasi dan selanjutnya merencakan sesuatu yang lebih dari pembelajaran yang telah dilalui dan siswa juga ingin aktif dalam proses pembelajaran.

Secara umum self regulation pada pembelajaran matematika agar terus ditingkatkan. Pembelajaran matematika harus dikembangkan untuk dapat mendorong self regulation dalam belajar. Hal tersebut sama dengan pendapat Kolb yang menyatakan bahwa dalam hal belajar siswa haruslah diberikan kesempatan yang luas untuk dapat mengonstruksi sendiri hasil pengetahuan yang telah dipelajarinya serta harus diberokan dorongan secara aktif agar dapat berinteraksi dengan lingkungan belajar sehingga memperoleh pemahaman yang lebih tinggi dari sebelumnya (Wardani, 2003). Salah satu cara yang dapat menigkatkan regulasi diri dalam belajar adalah dengan memberikan Latihan pada siswa.

Dalam penelitian yang dilakukan, membuktikan adanya pengaruh signifikan dari self esteem terhadap Prestasi Belajar. Dimana, semakin tinggi self esteem dalam belajar matematika akan mempengaruhi Prestasi Belajar matematika yang lebih baik.Faktor lain di luar self esteem juga mempengaruhi rendahnya prestasi belajar, dimana faktor luar tersebut yang mengakibatkan rendahnya self esteem dan mempengaruhi hasil belajar matematika, faktor lain tersebut dapat berasal dari orang tua yang menjadi sumber utama pembentuk self esteem, dimana pemberian yang berharga dari orang tua yaitu dengan meletakkan sebuah landasan self esteem yang kokoh. Teman atau orang terdekat dalam kehidupan sehari-hari juga sangat berpengauh terhadap pembentukan self esteem, dimana saat siswa berada di lingkungan sekolah maupun luar, siswa dapat menemukan teman yang memperoloknya, sehingga lingkungan akan menjadi kurang baik terhadap pertumbuhan self esteem yang sehat.

Oleh karena itu, pada langkah yang ditempuh untuk meningkatkan dan mengoptimalkan Prestasi Belajar siswa yaitu dengan meningkatkan self esteem (harga diri) siswa dalam belajar matematika. Siswa dengan harga diri akan membuat sebuah prestasi belajar yang rendah pula karena siswa tersebut cenderung untuk takut beradaptasi dengan lingkungannya, siswa juga selalu merasa takut, malu, dan merasa beda dari temannya yang lain. 
Harga diri merupakan aspek yang penting untuk menunjang Prestasi Belajar dalam kepribadian seseorang. Harga diri menjadi sebuah faktor yang menentukan perilaku dari individu. Setiap orang tentunya menginginkan penghargaan positif untuk dirinya sendiri, dimana penghargaan yang positif tersebut membuat seseorang merasakan dirinya berhasil, berharga, atau berguna bagi orang sekalipun dirinya masih memiliki kekurangan baik secara fisik maupun psikis. Apabila kebutuhan dari harga diri akan menghasilkan sebuah rasa percaya diri dan sikap optimis. Sebaliknya, apabila kebutuhan harga diri tidak terpenuhi maka akan membuat seseorang berperilaku negatif. Oleh karena itu, siswa dengan harga diri yang rendah cenderung akan mengalami kesulitan untuk mencapai sebuag kebahagiaan pada hidupnya sebagai akibat dari perasaannya sering berfikir negatif terhadap dirinya sendiri.

Dalam penelitian yang dilakukan, membuktikan adanya pengaruh signifikan antara self concept terhadap Prestasi Belajar. Dimana, semakin tinggi self concept dalam belajar matematika akan mempengaruhi Prestasi Belajar matematika yang lebih baik. Faktor lain di luar self concept juga mempengaruhi rendahnya prestasi belajar, dimana faktor luar tersebut yang mengakibatkan rendahnya self concept dan mempengaruhi hasil belajar matematika, faktor lain tersebut dapat berasal dari reaksi orang lain, dimana self concept dibentuk dalam waktu yang cukup lama dan dalam pembentukannya diartikan sebagai reaksi yang tidak biasa oleh seseorang dan dapat mengrubah self concept, serta apabila tipe reaksi seperti ini sering terjadi atau sering muncul pada orang dekat dari siswa seperti orang tua, teman dan lain-lain maka reaksi ini akan sangat berpengaruh pada konsep diri.

Oleh karena itu, langkah yang ditempuh dalam meningkatkan dan mengoptimalkan Prestasi Belajar adalah dengan meningkatkan self concept (konsep diri) siswa dalam belajar matematika. Konsep diri merupakan pandangan siswa berupa kepercayaan akan kelebihan dan kekurangan yang dimiliki diri yang berperang sebagai pendorong untuk melakukan usaha dalam penigkatan prestasi belajar.

Siswa dengan konsep diri yang baik tidak akan merasa cemas dalam menghadapi tantangan serta mampu mengatasi hambatan dalam belajarnya untuk meraih kesuksesan. Siswa dengan konsep diri tinggi akan mendukung tingginya hasil dari Prestasi Belajar matematika. Sebaliknya, siswa dengan konsep diri yang rendah akan memandang secara negatif lingkungan sekitar, tidak peduli, gelisah dan tidak memiliki keinginan untuk meraih keberhasilan belajar. Rendahnya konsep diri akan menyebabkan Prestasi Belajar yang rendah (Agustiani, 2006).

Berdasarkan dari pembahasan tersebut, maka penelitian ini dapat disimpulkan self regulation, self esteem dan self concept secara bersama memiliki sebuah pengaruh signifikan terhadap Prestasi Belajar matematika siswa kelas VIII SMP Negeri 5 Makassar. Hal ini dapat terlihat bahwa apabila self regulation, self esteem dan self concept meningkat, maka Prestasi Belajar matematika juga meningkat. Hal ini menunjukan bahwa self regulation, self esteem dan self concept berperan dan kontribusi yang penting terhadap Prestasi Belajar matematika siswa.

\section{SIMPULAN}

Simpulan dari penelitian ini menunjukkan Self Regulation, Self Esteem dan Self Concept secara bersama berpengaruh terhadap prestasi belajar peserta didik kelas VIII SMAN 5 Makassar dengan besar pengaruh 90,2\% dengan sisanya sebesar $9,8 \%$ yang terpengaruh oleh faktor lain. Oleh karena itu disarankan kepada pendidik untuk meningkatkan self regulation, self esteem dan self concept agar peserta didik prestasi belajar peserta didik semakin meningkat.

\section{DAFTAR PUSTAKA}

Agustiani, H. 2006. Psikologi Perkembangan Pendekatan Ekologi Kaitannya dengan Konsep Diri dan Penyesuaian Diri pada Remaja. Bandung: Refika Aditama.

Bryant, P. 2007. Self-regulation and decision heuristics in entrepreneurial opportunity evaluation and exploitation. Management Decision.

Desmita. 2009. Psikologi Perkembangan Peserta Didik. Bandung: Remaja Rosdakarya.

Emler, N. 2001. Self-Esteem: The Costs and Causes of Low Self-Worth. York Publishing Services.

Erman, S., Turmudi, Suryadi, D., \& Herman, T. 2003. Strategi Pembelajaran Matematika Kontemporer. JICA Universitas Pendidikan Indonesia.

Friskilia, O., \& Winata, H. 2018. Regulasi Diri (Pengaturan Diri) Sebagai Determinan Hasil Belajar Siswa Sekolah Menengah Kejuruan. Manper: Jurnal Pendidikan Manajemen Perkantoran, 3(1).

Gufron, M. N., \& Risnawati, R. 2016. Teori-Teori Psikologi. Ar-Ruzz Media.

Indrawan, R., \& Yaniawati, P. 2014. Metodologi 
Ummi Rofika Hasan, Fitriani Nur, Ulfiani Rahman, Suharti, dan Eka Damayanti Anargya: Jurnal Pendidikan Matematika, Vol. 4 No.1, April 2021 https://dx.doi.org/10.24176/anargya.v4i1.5715

Penelitian Kualitatif dan Campuran untuk Manajemen, Pembangunan, dan Pendidikan. PT. Rafika Aditama.

Mahayukti, G. A., Dewi, P. K., \& Hartawan, I. G. N. Y. 2020. Pengaruh Pembelajaran Berbasis Masalah dengan Penilaian Diri terhadap Efikasi Diri dan Hasil Belajar Mahasiswa. Jurnal Anargya, 3(2), 88-95.

Mruk, Christopher J., P. 2006. Self-Esteem Research, Theory, and Practice: Toward a Positive Psychology of Self-Esteem. In Journal of Chemical Information and Modeling.

Nurafni, A., \& Pujiastuti, H. 2019. Analisis Kemampuan Koneksi Matematis ditinjau dari Self Confidence Siswa: Studi Kasus di SMAKN 4 Pandeglang. Jurnal Anargya, 2(1), 27-33.

Sudjana, N. 2009. Penilaian Hasil Proses Belajar Mengajar. PT Remaja Rosdakarya.

Sudjana, Nana. 2009. Penilaian Hasil Proses Belajar Mengajar. Bandung: Remaja Rosdakarya.

Sumartini, T. S. 2014. Penerapan Model Pembelajaran Concept Attainment Untuk Meningkatkan Kemampuan Penalaran Matematis Dan Self Concept Siswa SMP: Studi Kuasi Eksperimen Pada Kelas VIII di Salah Satu SMP Negeri Tarogong Kaler Garut. Universitas Pendidikan Indonesia.

Syah, M. 2008. Psikologi Pendidikan dengan Pendekatan Baru. Bandung: Remaja Rosdakarya.

Tamaruddin, A., \& Fathurohman, I. 2020. Analisis Faktor Otentik Kesulitan Belajar Program Linear Berbasis Problem Based Learning. Jurnal Anargya, 3(1), 8-14.

WARDANI, I. 2003. Penelitian Tindakan Kelas. Jakarta: Karunika Universitas Terbuka.

Williamson, G. 2015. Self-Regulated Learning : An Overview of Metacognition, Motivation, and Behaviour. Journal of Initial Teacher Inquiry, 25-27.

Zamnah, L. N. 2019. Analisis Self Regulated Learning yang Memperoleh Pembelajaran Menggunakan Pendekatan Problem Centered Learning dengan Hands-On Activity. Jurnal Anargya, 2(1), 54-61.

Zimmerman, B. J. 2000. Attaining SelfRegulation: A Social Cognitive Perspective. Handbook of Self-Regulation, 13-29.

Zimmerman, B. J., \& Cleary, T. J. 2004. SelfRegulation Empowerment Program: A School-Based Program to Enhance SelfRegulated and Self-Motivated Cycles of
Student Learning. Psychology in the Schools, 41(5), 537-550.

Zulfikar, R. N., \& Tamrin, M. 2019. Pengembangan Modul Matematika dengan Pendekatan Metakognitif untuk Memfasilitasi Kemandirian Belajar Siswa SMK Muhammadiyah Kupang. Jurnal Anargya, 2(2), 70-74. 